\title{
How many cells are supposed to be counted on the specular microscopy exam?
}

\author{
Quantas células contar no exame de microscopia especular?
}

Based on the article published with the title of Corneal specular microscopy in infectious and noninfectious uveitis ${ }^{(1)}$, some brief comments about the specular microscope and the methodology used must be made.

The specular microscope SP2000P on its version without the complementary Imaginet software for corneal endothelium, does not allow images recording for later analysis, despite not being able to obtain images of various areas of the endothelial mosaic or even focus on the areas of interest ${ }^{(2)}$. Upon repeating the same exam three times with the contact specular microscope on the central area of the endothelial mosaic with the patient staring at the same target, it is probable that part of the obtained endothelial image in one of the images may repeat itself on both others, because when the target is starred by the patient, the ray of light generated by the flash of the specular microscope tends to be reflected around the same region of the endothelial mosaic. In a sampling process, the necessary images must always be different; on the other hand three other analysis can be done on the same image.

Having the cells been considered only once for endothelial analysis purpose, the number of cells to be included in the sampling process of the endothelial exam may be discussed.

In 1976, Laing et al. suggested that at least 30 endothelial cells per image ${ }^{(3)}$ should be considered. Doughty et al. suggested that at least 75 cells should be counted per image ${ }^{(4)}$. Inaba et al. preferred to include at least 100 cells per image ${ }^{(5)}$. Binder et al. suggested the inclusion of all cells of at least three images of the central and paracentral regions ${ }^{(6)}$. These four references are mentioned by McCarey et al. in the article named Review of corneal endothelial specular microscopy for FDA clinical trial of refractive procedures, surgical devices, and new intraocular drugs and solutions ${ }^{(7)}$ using as reference the article now being mentioned ${ }^{(1)}$.

The use of 10 to 20 cells, as recommended by the equipment manual instructions, is reckless, as this manual must have been written over two decades ago. From that time until now, the understanding of the number of endothelial cells necessary for an exam has changed ${ }^{(4-6,8-9)}$. The Cells Analyzer software calculates the statistical significance of endothelial samples obtained by the specular microscopy ${ }^{(9)}$, with all endothelial data described on figure 1 of the article (endothelial density 2,026 cells $/ \mathrm{mm}^{2}$, area $493.5 \mu \mathrm{m}^{2}$ and coefficient of variation of 30 ) which 12 cells are counted; the calculated sample error is $17 \%$ when it should be less than $5 \%$ for a confidence degree of $95 \%$, i.e., sample error $340 \%$ superior to the accepted by the medical science $(5 \%)$. In case two other images with similar results are included on the sampling process, the error will reduce to $9,8 \%$ and still, it would be necessary at least more than 102 cells for the sample size to be considered correct. Besides, the clustering effect was not considered ${ }^{(7)}$.

The analytical resources of the article being discussed show statistical equality among the studied groups, thus they do not correct the inherent sample error of the performed exams.

On the study mentioned, endothelial abnormalities secondary to uveites do not jeopardize the use of the Cells Analyzer, conversely, they help the examiner to obtain more accurate and reproductive results. The Cells Analyzer orients the examiner to obtain samples of the correct size, to determine the minimum number of cells to be included on the sampling process, optimizing the time spent to perform the specular microscopy. It also calculates the sample error existing in one exam, whether with one or more endothelial images.

In case the purpose of the exam is to obtain endothelial screening and not to compare it with past or future exams, a sample error of little above $5 \%$ may be accepted, and in case one wants to compare exams regarding the time, the sampling rigor is crucial. In case specular microscopy is performed for scientific purposes, the rigor of the sampling of every exam must be followed to avoid the methodological error that involves the specular microscopy already identified by the FDA in $1999^{(10)}$.

Fernando Cesar Abib

Correspondence address: Fernando Cesar Abib. Av. João Gualberto, 1.731 - Loja 2 -
Curitiba (PR) - CEP 80030-001

\section{REFERENCES}

1. Oliveira F, Oliveira Motta AC, Muccioli C. Corneal specular microscopy in infectious and noninfectious uveitis. Arq Bras Oftalmol. 2009;72(4):457-61.

2. Abib FC. Microscopia especular de córnea: manual e atlas. Rio de Janeiro: Revinter-RioMed; 2001. Aparelhos disponíveis no mercado. p.29-34.

3. Laing RA, Sanstrom MM, Berrospi AR, Leibowitz HM. Changes in the corneal endothelium as a function of age. Exp Eye Res. 1976;22(6):587-94. Review.

4. Doughty MJ, Muller A, Zaman ML. Assessment of reliability of human corneal endothelial cell-density estimates using a noncontact specular microscope. Cornea. 2000;19(2):148-58

5. Inaba M, Matsuda M, Shizaki Y, Kosaki H. Regional specular microscopy of endothelial cell loss after intracapsular cataract extraction: a preliminary report. Acta Ophthalmol (Copenh). 1985;63(2):232-5

6. Binder PS, Akers P, Zavala EY. Endothelial cell density determined by specular microscopy and scanning electron microscopy. Ophthalmology. 1979;86(10): 1831-47.

7. McCarey BE, Edelhauser HF, Lynn MJ. Review of corneal endothelial specular 
microscopy for FDA clinical trial of refractive procedures, surgical devices, and new intraocular drugs and solutions. Cornea. 2008:27(1):1-16.

8. Melo CM, Santos PM, Santos RC, Abib FC. [Using of Cells Analyser software in the study of image of corneal specular microscope endothelial samples]. Arq Bras Oftalmol. 2008;71(1):79-82. Portuguese. Erratum in: Arq Bras Oftalmol. 2008;71(3):414.
9. Laing RA. Specular microscopy. In: Brightbill FS, McDonnell PJ, McGhee CNJ, Farjo AA, Serdarevic ON. Corneal surgery, theory, technique and tissue. $4^{\text {th }}$ ed. New York: Elsevier; 2009. p.105-16.

10. Food and Drug Administration. FDA's role. Summary of safety and effectiveness data [Internet]. Washington: Department of Health \& Human Services; 1999. [cited 2008 Jul 29]. Available from: www.fda.gov/cdrh/pdf/P960033b.pdf

\section{anc}

\section{$10^{\circ}$ Congresso da Sociedade de Oftalmologia do Triângulo Mineiro}

\section{$1^{\circ}$ Congressso de Oftalmologistas dos EX-alunos e EX-Residentes da UFTM}
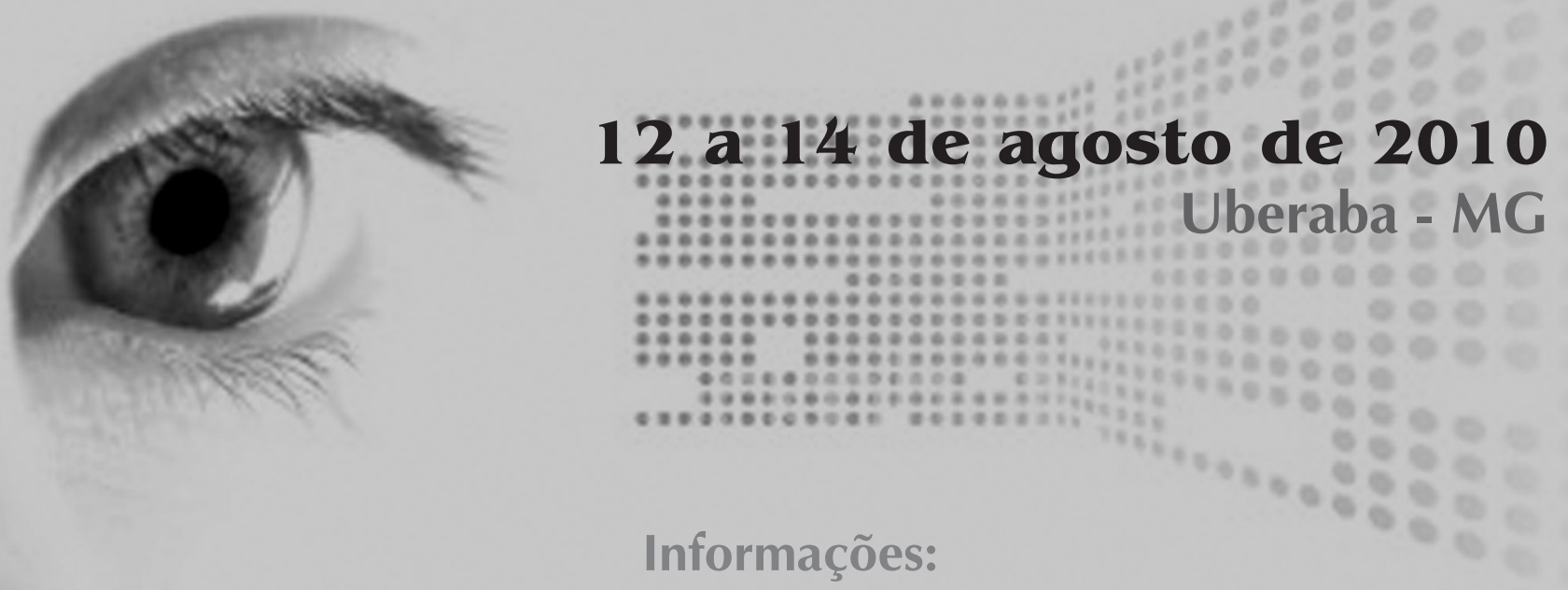

Tel: (34) 3312-0657 


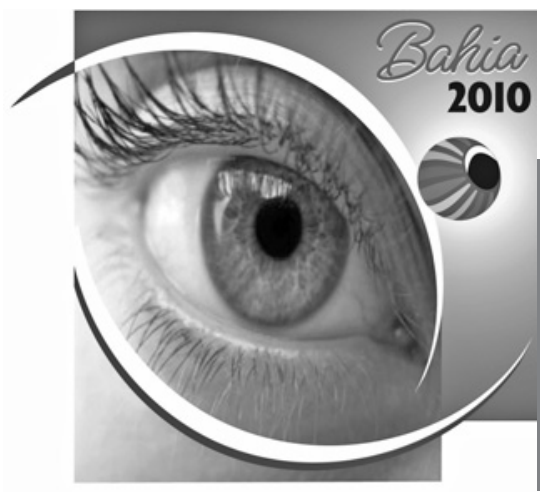

\section{Congresso Brasileiro de}

\section{Prevenção da Cegueira e Reabilitação Visual}

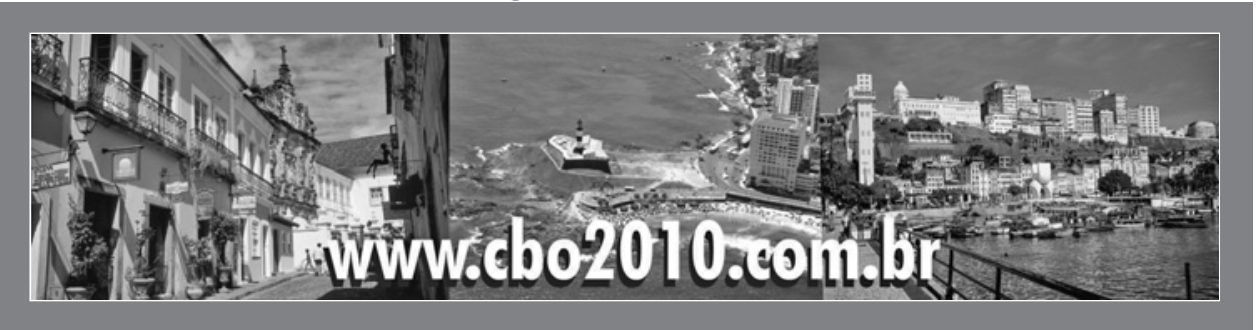

\begin{tabular}{|l|c|c|}
\hline CATEGORIA & Até $\mathbf{2 3} / \mathbf{0 8} / \mathbf{2 0 1 0}$ & NO LOCAL \\
\hline Sócios CBO & $\mathrm{R} \$ 450,00$ & $\mathrm{R} \$ 550,00$ \\
Alunos Cursos Credenciados & $\mathrm{R} \$ 450,00$ & $\mathrm{R} \$ 550,00$ \\
\hline${ }^{* * *}$ Residentes & $\mathrm{R} \$ 500,00$ & $\mathrm{R} \$ 600,00$ \\
*Acadêmicos $^{* *}$ Áreas Afins & $\mathrm{R} \$ 500,00$ & $\mathrm{R} \$ 600,00$ \\
Curso (2 Cursos de 2 Horas) & $\mathrm{R} \$ 500,00$ & $\mathrm{R} \$ 600,00$ \\
Dia Especial & $\mathrm{R} \$ 50,00$ & $\mathrm{R} \$ 80,00$ \\
Acompanhantes & $\mathrm{R} \$ 300,00$ & $\mathrm{R} \$ 400,00$ \\
\hline
\end{tabular}

Médico Não-Sócio:

Caso o dr(a). deseje se inscrever no evento, acesse o site www.cbo.com.br e imprima seu boleto para pagamento da anuidade 2010. Para impressão do boleto é necessário efetuar seu login. Caso não possua login e senha, entre em contato através do e-mail cadastro@cbo.com.br ou pelo telefone (11)3266-4000.

\section{- Valor da anuidade CBO 2010 - R\$ 480,00}

*Acadêmicos: $\quad$ aluno da faculdade de medicina deverá enviar uma declaração da secretaria da instituição de ensino por fax para (71) 3011-9797.

**Áreas Afins: Engenheiro, Enfermeiro, Psicólogo, Pedagogo, Fonoaudiólogo, Terapeuta Ocupacional, Fisioterapeuta, Veterinário, Administradores, Ortoptistas. O comprovante de ocupação (cópia da identidade profissional)
deve ser enviada para a Secretaria Executiva do Congresso, Interlink Eventos, por fax nº (71) 3011-9797.

***Residentes: Enviar o documento de comprovação do supervisor do Curso/COREME para o fax (71) 3011-9797.

Não serão aceitas inscrições de optometristas.

Cancelamento de inscrição: somente serão reembolsadas taxa de inscrição no Congresso mediante solicitação escrita (carta, e-mail ou fax) encaminhada para a secretaria executiva até o dia $\mathbf{2 9}$ de agosto de 2010. As devoluções serão feitas mediante pagamento de $10 \%$ do valor da inscrição para ressarcimento de custos operacionais. Após esta data não haverá devolução.

\footnotetext{
A inscrição de acompanhante dará direito a:

- Transporte dos hotéis credenciados para o local do evento (Centro de Convenções)

- Crachá para circulação no local do evento para as atividades sociais (após as 18 h00 e exceto para as salas com atividades científicas)

- 01 Sacola
}

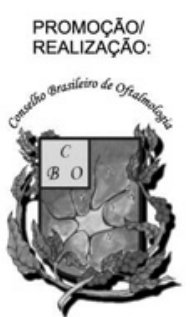

- Quarta-feira 29/09/2010 Centro de Convenções-Cerimônia de Abertura, Cocktail e Show com Banda Baiana

- Quinta-feira 30/09/2010 Centro de Convenções-HappyHour

- Sexta-feira 01/10/2010 Local a definir - Festa de Confraternização (Festa de Largo) 